\title{
OBSERVATIONS ON SILAGE MAKING OF LANDSCAPE CONOCARPUS BROWSE RESIDUES AS FEED INGREDIENT IN KUWAIT
}

\author{
Z. BAROON ${ }^{1} \&$ M.A. RAZZAQUE ${ }^{2}$ \\ ${ }^{1}$ Biotechnology Department, Kuwait Institute for Scientific Research, Kuwait. \\ ${ }^{2}$ Aridland Agriculture and Greenery Department, Kuwait Institute for Scientific Research, Kuwait.
}

\begin{abstract}
There is a chronic shortage of local feeds in Kuwait, and almost 95\% of total feeds are expensively imported. Therefore, efforts were focused to explore the possible utilization of locally available landscape browse residues as feed ingredients. Landscape greenery residues have increased with locally implemented greenery programs. Conocarpus lancifolius is an ornamentally predominant tree among landscape plantations, daily resulting in over $120 \mathrm{t}$ of residual by-products without being utilized. Ensiling, was considered as a technically sound strategy for proper utilization of Conocarpus residues as an upgraded feed ingredient substituting imported conventional feeds. A total premix of $24 \mathrm{t}$ of silage was prepared in pilot-scale trench silos for 30 days. Nutritional value of Conocarpus silage was evaluated, where mean values of $4.2 \pm 0.12,4.95 \pm 0.32 \%$, and $7.3 \times 108 \pm 0.12$ colony forming units $(\mathrm{CFU}) / \mathrm{g}$ of silage for $\mathrm{pH}$, lactic acid, and lactic acid bacteria were achieved, respectively. Palatability and feeding trials were performed for four months on 60 growing heifers of Holstein-Friesian breed grouped in six dietary treatments. Formulated feed rations contained 20, 30, 40, 50 and $60 \%$ silage partially replacing conventional roughages (alfalfa, hay straw). Control dietary treatment contained $100 \%$ conventional feed ingredients. Daily dry matter intake and feed conversion ratio were significantly $(p>$ 0.05 ) high. Results showed that grossly $40 \%$ of the conventional roughages could be replaced by the ensiled Conocarpus greenery browse residues. Cost/benefit analysis was carried out on pilot-scale production of Conocarpus silage, confirming a feasible, low cost, and competitive product where the cost was calculated to be Kuwaiti Dinar 33 (US\$ 120)/t silage. Break-even point could be achieved after 30 months with production of 3,159 t silage. Potentially, low-cost Conocarpus silage could partially substitute expensive imported roughages, thereby alleviating feed shortage and, currently, promoting livestock production.
\end{abstract}

Keywords: competitive, ensiling, feasible, imported, nutritional, palatability, shortage.

\section{INTRODUCTION}

There is a chronic shortage of local animal feeds in Kuwait, and almost 95\% of animal feed ingredients, such as barley, corn, alfalfa, wheat bran, soybean meal, limestone, vitamin, and mineral mixture, are imported at expensive prices. The increasing greenery implementation programs in Kuwait has resulted to an increase in landscape plantations residues, thereby aggravating environmental pollution due to onsite deterioration of the residues beside random dumping and landfills. Ensilage of these landscape residues introduces a cost effective, upgraded and unconventional feed ingredient substituting the expensively imported conventional ingredients such as alfalfa and wheat straw. Conocarpus lancifolius silage was introduced as a substituted forage ingredient and was qualitatively and quantitatively evaluated insight into animal palatability trials. Believing in the importance of research and development (R\&D) in feed availability, Kuwait Institute for Scientific Research (KISR) implemented research studies in domestic silage-making from the ever-increasing landscape plantations greenery residues. This review addresses the potential value of landscape Conocarpus browse greenery residues as unconventional sources of upgraded feed ingredient for livestock, and currently introduces the technical feasibility for local silage production. The main innovation of this research focused on ensilage techniques and palatability trials. The flow of consolidating cooperation through crosscountry networks was achieved among the national scientists and livestock producers. 


\section{SHORTAGE OF FEEDS IN KUWAIT}

Kuwait is a part of the Arabian Peninsula where the forage production, either in rangelands or irrigated pasture, is very limited due to climatic factors and water scarcity [1-4]. Rangelands can hardly provide about $15-20 \%$ of the total forages needed for grazing animals, therefore, and due to the chronic shortage of local animal feeds, almost $95 \%$ of the total feeds are imported [5] and consequently about $70 \%$ of the total costs of the livestock production are attributed to feed [6]. Estimated feed prices showed that the demand for animal feeds, both concentrates and roughages, will increase to about 283,000 metric tons to $1,150,000$ metric tons by the year 2015 [7-9]. Thus controlling feed cost is a major way to control the total costs of animal production [10]. Therefore, multidisciplinary efforts were urged to explore the possibility of locally available resources of landscape plantations residual byproducts to be utilized as alternative unconventional feed ingredients.

\section{LANDSCAPE GREENERY BROWSE AND BYPRODUCTS RESIDUES}

Various landscape trees, palms, shrubs, grasses, and lawns are planted through contractual greenery programs and agreements between domestic agricultural companies and the Public Authority for Agriculture and Fishery Resources (PAAFR) in Kuwait. Conocarpus lancifolius is the most massively predominant landscape plant species in landscape and highways throughout the country. C. lancifolius, is one of two Conocarpus species in the family Combretaceae and might be grazed, preserved, or ensilaged [11]. Because of its high salt tolerance and moderate drought tolerance, Conocarpus trees and shrubs are extensively used in landscaping and ornamentally planted as a pioneer abundant tree in reforestation projects and greenery programs in Kuwait and throughout the Arabian Peninsula [12]. The increasing number of greenery implementation programs in the country has resulted in increasing the greenery browse and byproducts residues thereby aggravating environmental pollution due to dumping and landfills beside onsite deterioration of the plantation residues. Conocarpus tree is available year round and more than $120 \mathrm{t}$ of landscaping residual byproducts are produced daily in Kuwait. Although a small proportion of the raw greenery browse is fed to the ruminants, most are generally incinerated or dumped [13]. Hence, Conocarpus greenery browse residues might be potentially utilized and ensiled as costeffective and alternative forages in livestock feeding systems [14]. Conocarpus is reported as nontoxic, palatable, and attractive to feeding animals [15, 16]. Al-Surrayai and Baroon [17] in Kuwait and Wensvoort [18] in United Arab Emirates (UAE) carried out the studies to evaluate the potential suitability of browse and produced green wastes from $C$. lancifolius for silage to feed to domestic and exotic animals. Conocarpus greenery residues were potentially considered an unconventional feed ingredient for ensiling, as being reported by earlier studies [19-21] conducted in KISR.

\section{SILAGE MAKING}

Silage technology has opened the possibility for utilizing green residues for feeding livestock [22]. As a technically sound method, ensiling is considered the most proper utilization of greenery byproduct residues and a convenient preserving method with optimal quality and quantity and minimal natural losses [23]. Ashbell et al. [24]. and El-Shaer [25] highlighted ensilage as a potential livestock fodder in arid and semi-arid areas. The subject of silage in its scientific facets has been covered in the monographs of Woolford and Pahlow, [26], Kung and Muck, [27], MacDonald et al., [28], Woolford, [29], and Whittenbury [30]. Fermentation inoculants with efficient homofermenta-

tive lactic acid bacteria that enhance silage preservation and feeding value for livestock were described in many literature publications [31-36]. 


\section{RESEARCH AND DEVELOPMENT SILAGE MAKING STUDIES}

As a part of the Strategic Research Program of KISR (2000-2005) and the Agricultural Master Plan 1995-2015, [37], the emphasis was mainly given on animal feeds. Potentially, governmental and private interests had been developed to utilize the upgraded landscape greenery residues as unconventional ingredients substituting conventional forages in animal feed [38]. Earlier studies on nutritional evaluation of protein-enriched fermented fodder and silage prepared from corrugated cardboard and date palm leaves as dietary ingredients for sheep and dairy calves were conducted by Razzaque et al., [39], Bahman et al., [40], and Armstrong et al. [41]. where the obtained results had significantly shown the potential for utilizing ground corrugated cardboard and date palm leaves for livestock feeding.

Recently, the possibility of utilizing landscape greenery residues as untraditional feed ingredients had been investigated. Since the year 2000, KISR conducted joint research and development (R\&D) silage making projects to address the potential value of landscape Conocarpus greenery browse and byproducts residues as unconventional feed ingredient followed by evaluating the formulated feed ration containing silages for ruminants, and investigating the cost/benefit of future silage production. Experimental laboratory mini- and pilot-scales silage preparations were previously undertaken in studies conducted earlier in 2001, 2003, 2004, and 2006. From the findings of these studies, Conocarpus silage that is described in this paper was considered as a good quality silage with applications of microbial inoculants at a rate of $2.0 \times 10^{9} \mathrm{cfu} \mathrm{kg}^{-1}$ and molasses at a rate of $6 \%$ as silage additives.

Research outcomes were strongly recommended to be implemented in management practices for livestock producers to adopt ensilage technique to be involved in the optimization of animal feeding system in Kuwait. A reviewed evaluation of applied silage-making technology is reported for pilotscale production of Conocarpus silage before the commercial-scale production bearing the appropriate costing of a domestically profitable silage making.

\subsection{Pilot-scale Conocarpus silage production}

Constructed 21 trench silos (dimensions of $10 \times 6 \times 2.5 \mathrm{~m}$ ) were prepared with approximately a maximum filling capacity of 20-22 $\mathrm{t}$ for each trench with the upper edge of each trench on one side, was designed with a $20^{\circ}-30^{\circ}$ slope. Fresh browse and greenery residues of Conocarpus were collected from landscape and highway plantations by the House of Development (HOD) for Agricultural Contacting Company, a private entrepreneur for greenery plant maintenance. From the findings of earlier KISR - conducted studies - Conocarpus silage was considered a good quality silage. The silage was prepared where the browse, consisting of residual green leaves and small branches, was shredded into 1-2 cm lengths using a wood chipper (AB Alvan Blanch, UK). A total of six trench silos were filled with an average of $24 \mathrm{t}$ plant material in each trench. A commercial microbial inoculum, 'Silak®', was added as a microbial suspension at an application rate of $5.0 \mathrm{~kg} \mathrm{t}^{-1}$ with $2.0 \times 10^{9} \mathrm{cfu} \mathrm{kg}^{-1}$. The inoculum included a consortium of Lactobacillus species (L. plantarum, L. caesi, and L. bulgaricus) and enzymes (amylase and cellulase). Molasses was added at a rate of $6 \%$ during the ensiling process by electric pasteurizing sprayers. Silages were compacted in progressive layers using a wheeled Caterpillar tractor with a frontend loader, to minimize the exposure of silage to air before covering. A total of $24 \mathrm{t}$ of Conocarpus silage in 21 trench silos were prepared. Each trench was filled to a height of $50 \mathrm{~cm}$ above the surface of the ground and then covered with a plastic sheet. Finally the trench was covered with a layer of 0.5 to $1.0 \mathrm{~m}$ of soil to provide continuous pressure and compaction of the ensiled premix. Consecutively, Conocarpus silages underwent anaerobic fermentation for a period of 30 days. 


\subsection{Qualitative and quantitative nutritional evaluation of Conocarpus silage}

Visual factors, such as color, odor, and general appearance, provide a good indication of the expected overall nutritive value. Coupled with the chemical analysis, microbiological determination indicates the nutritive quality of the produced silage. Therefore, it is extremely important that representative samples of the silage be obtained for quality determinations by conducting the nutritional evaluation and microbiological examination of the produced silage.

After 30 days of anaerobic fermentation, representative triplicate samples of each trench were taken for qualitative and quantitative nutritional determinations. The $\mathrm{pH}$ values of fresh wet silage samples were measured by $\mathrm{pH}$ meter. Chemical analyses were carried out according to AOAC method [42]. Samples for chemical analyses were freeze-dried, and then, ground to pass through a 1 to $2 \mathrm{~mm}$ sieve. Dry matter (DM) content was determined by the removal of water using toluene distillation with ethanol correction [43]. The crude protein (CP) was calculated as $\mathrm{N} \times 6.25$. Crude fiber content was determined according to the methods described by Goering and Van Soet [44]. Volatile fatty acids and ethanol were determined by gas chromatography with a 25 m medium bore capillary column and helium (He) as the carrier gas. Water soluble carbohydrates (WSC) were determined by quantitative determination of total available carbohydrates and the absorbance was measured at $625 \mathrm{~nm}$ according to the spectrophotometric method of McDonald and Henderson [45]. Contents of organic acids: lactic, acetic, propionic, butyric acids, were determined by highperformance liquid chromatography (HPLC) with ultraviolet (UV)-visible detector [46]. The microbial counts of fresh silage samples were calculated using the plate count method and serial dilutions of $10^{1}$ and $10^{8}$ (10-fold) were prepared for counting viable bacteria, fungal (yeasts and molds) and lactic acid bacteria (LAB) populations. An aliquot of $0.1 \mathrm{~mL}$ of each dilution was spread on the surface of the agar plate. The bacterial and fungal counts were enumerated on nutrient agar (NA) and potato dextrose agar (PDA) plates (Difco Laboratories, Michigan, USA), respectively. The LAB were counted on plate count agar (PCA) (Difco Laboratories, Michigan, USA) containing bromoresol purple using anaerobic jars (BBL, GasPak ${ }^{\mathrm{TM}}$, USA). Colonies were counted directly on the agar as colony-forming units (cfu)/g of fresh silage. AflaCup ${ }^{\mathrm{TM}} 20$ (Romer ${ }^{\circledR}$ Aabs, Inc., USA) test was used for the qualitative determination of total aflatoxins in silage samples.

\subsection{Animal feeding studies and palatability}

The feeding trial comprised a preliminary adaptation period of 28 days, followed by an experimental 120 days period. The diets were formulated to be isonitrogenous and isocaloric. Feeding dairy heifers balanced diets was considered important, where the balanced diet was fed in the form of total mixture ration (TMR) as mixture of forage and grains, fed once daily. Based on current research for growing heifers feeding, [47], heifers were fed diets containing 14 to $14.5 \% \mathrm{CP}$ to demonstrate the maximum protein efficiency. Corn and soybean meal were added as standard concentrate sources to provide energy and protein. Vitamins and minerals were included. Wheat straw and alfalfa cubes and pellets were the basal roughages used in this experiment for feeding. The grouped animals were distributed randomly into six formulated dietary treatments T1, T2, T3, T4, T5, and T6, with 10 heifers in each treatment. The formulated diets were composed of mixed concentrates and roughages in the ratio of 40:60 as illustrated in Table 1. The control treatment, designated as T1, was a basal diet that totally contained $40 \%$ of the concentrate mixture and $60 \%$ of conventional feed roughages (30\% alfalfa hay and $30 \%$ straw) with no silage included. Dietary treatments T2, T3, T4, T5, and T6 contained 40\% equal portions of the concentrates and contained 20, 30, 40, 50 and 60\% Conocarpus silage, respectively replacing the total conventional roughages. Basic mixed concentrates in the dietary treatments, 
Table 1: Formulated feeding rations for heifers \% on DM basis.

\begin{tabular}{lccc}
\hline Dietary treatment* & Alfalfa hay & Straw & Conocarpus silage \\
\hline T1 & 30 & 30 & 0 \\
T2 & 20 & 20 & 20 \\
T3 & 15 & 15 & 30 \\
T4 & 10 & 10 & 40 \\
T5 & 0.5 & 0.5 & 50 \\
T6 & 0.0 & 0.0 & 60 \\
\hline
\end{tabular}

*Dietary treatment $=\mathrm{T} 1$ (control) contained $60 \%$ conventional roughage (alfalfa hay and straws). T2, T3, T4, and T5 contained 20,30, 40, and 50\%, respectively of Conocarpus silage partially substituted conventional DM of roughages. T6 contained $60 \%$ silage with no conventional roughage. Equally, all treatments contained $40 \%$ mixed concentrates of basal ingredients, that is, 14.6, 2.8, $10.0,10.0,1.0,1.0,0.3$, and $0.3 \%$ of barley, corn, wheat bran, soybean meal, vitamin and mineral supplements, limestone, salt, and sodium bicarbonate, respectively.

including T1, were comprised of barley, corn, wheat bran, soya bean meal, vitamin and mineral supplements, limestone, salt, and sodium bicarbonate at 14.6, 2.8, 10.0, 10.0, 1.0, 1.0, 0.3, and 0.3\% on DM basis, respectively. A total of 60 Holstein-Friesian heifers, 10 months old with initial live weights ranging from 262 up to $275 \mathrm{~kg}$, were housed in a shed having pens and each fitted with a manger and water trough, for each group. Prior to the trials, the animals were vaccinated for infectious diseases. Repeated two doses of anthelmantics were administered for internal and external parasite control. Heifers were randomly grouped into six groups, with 10 heifers per treatment. The animals were initially fed with basal diet of concentrate mixture and alfalfa hay ad libitum for a week. During the 28 days of habituate period and 120 days of the main trial period, clean and safe drinking water and rock salt lick blocks were provided for animals, ad libitum. Then gradually, Conocarpus silage was introduced to the animals over a period of three weeks of adjustments to their feed rations and new housing. This period followed ad libitum feeding of experimental rations, and daily feed DM intakes consumed by the heifers were determined. Live weight gains of heifers were taken once every month, prior to feeding time. Weighing the animals once every month with a 12-h retrieving food was done before every morning feeding and the results were calculated for each 30-day periods. Average daily gain during each period by the following formula was calculated. Feed conversion ratio (FCR) by the amount of feed consumed per unit of live weight was calculated every 30 days as well as in total of the experimental period was marked by the following equation: $\mathrm{FCR}=\mathrm{DM}$ intake $(\mathrm{kg}) / \mathrm{amount}$ of weight gain $(\mathrm{kg})$. The animals were fed twice a day, half the total amount of feed in the morning and the other half in the evening. The level of diets was determined during the adjustment period with specific emphasis on their nutritional needs, such as DM, protein and energy, according to NRC standards [48]. The leftover feeds, either mixed diets with conventional roughages or silage were collected in the following morning and the residual amounts were recorded. Refusals were quantified daily for adjustment of the next day's feed allocation, to allow ad libitum consumption of rations (10\% refusals).

\subsection{Statistical data analysis}

Data on variations in nutritional composition of silage samples were evaluated by analysis of variance. The significance of differences among means was tested by the multiple range test according 
to Duncan, [49], and the significance was accepted at the $p<0.05$ level. Feed intake and feed conversion efficiencies were subjected to analysis of variance assuming a randomized block design and treating blocking group as a random effect as described by Payne et al. [50].

\subsection{Cost/benefit analysis}

The financial analysis of the pilot-scale production of $24 \mathrm{t}$ of Conocarpus silage was carried out where total variable and fixed costs were compared with the sales revenue to determine the level of sales volume and the price of the produced silage.

\section{RESULTS AND DISCUSSION}

\subsection{Nutritional evaluation of Conocarpus silage}

On opening the trench silos after 30 days, the physical wet texture and the smell indicated the anaerobic fermentation of the silages. Organoleptic observations is a practically the simplest method to evaluate the quality of the silage. Variations in the odor among the silages were insignificant. Odor is suggested as one of the organoleptic characters that best shows the fermentative quality of silage $[51,52]$. The color of the silages ranged from green to greenish brown. It was suggested that the addition of molasses increased the degree of brown color in the silages. Based on the smell and color, the silages were considered to be acceptable. The mean values $\pm \mathrm{SD}$ of the nutritional parameters and microbial counts of the Conocarpus silage are shown in Table 1. The six replicates of Conocarpus silage prepared in six trenches were similarly prepared. Hence, means of fermentation, nutritional, and microbiological parameters were calculated. Statistically the variations among $\mathrm{pH}$ values were not significant with acceptable mean $\mathrm{pH} \pm \mathrm{SD}$ of $4.2 \pm 0.12$ (Table 1). The $\mathrm{pH}$ is the most single indicator of the nutritive value of silage. Overall, $\mathrm{pH}$ values indicated good quality and wellpreserved silages. The lower the $\mathrm{pH}$ the better, since it indicates that a lactic-acid type of fermentation has occurred. Under anaerobic conditions, the low $\mathrm{pH}$ of silage inhibits the growth of undesirable microorganisms such as clostridia [53]. High $\mathrm{pH}$ values indicate poor forage fermentation, characterized by high levels of butyric acid [54]. In general, silage is considered to be of good quality with $\mathrm{pH}$ values below 4.5 [55-57] and moisture content between 75 and 65\% [58, 59]. Silage quality is basically measured the DM, CP, crude fiber, and ash contents. Mean CP content was $11.18 \pm 0.07$ on DM basis, which was considered to be adequately palatable for livestock feeding. In general, silage is considered palatable with a protein content ranging from 7.3 to $9.8 \%$ on DM basis [60, 61]. The high ammonia concentration ( $>12$ to $15 \%$ of $\mathrm{CP}$ ) can affect the fermentation and quality of silage and may have an adverse effect on animal performance [62,63]. Mean crude fats content was $2.47 \pm$ 0.21 on DM basis, as shown in Table 1, and was within the recommended level for a good quality silage. Jalčl et al. [64]. reported that fat concentrations in the silage are mainly due to the lipids in the microbial cells as well as those of the ensiled plant materials. Mean crude fiber contents of the silage were $20.85 \pm 0.95$ on DM basis (Table 1). As reported by Selmer-Olsen et al. [65]. the lactic acid of silage partially hydrolyzes the crude fiber and synergistically enhances the enzymatic activity of cellulase through a slow chemical hydrolysis. Crude fibers are divided into acid detergent fibers (ADF) and neutral detergent fiber (NDF) of cellulose, lignin, and hemicellulose. As a rule of thumb, the maximum NDF in the DM of the daily feed ration should be from 1.2 to $1.5 \%$ of the animal body weight $[66,67]$. Mean ash content of the silage was $19.53 \pm 0.53$ on DM basis also shown in Table 1 . High lactic acid concentrations were detected with a mean value of $4.95 \pm 0.32 \%$ on DM basis (Table 1). Lactic acid is the single most important indicator of a good anaerobic fermentation, and at 
least $65-70 \%$ of total silage acids in good silage should be lactic acid [68, 69]. High levels of acetic acid $(>3 \%)$ suggest inefficient silage fermentation, and very high levels $(>5 \%)$ may decrease DM intake in dairy cattle. Acceptable lactic acid to acetic acid ratio was reported (3.38 $\pm 0.11: 1.0)$ as shown in Table 1. Microbial inoculants with LAB generally has a positive effect on silage characteristics in terms of lower $\mathrm{pH}$ and shifting fermentation toward high lactic acid concentration and low acetic acid concentrations [70]. The ratio of lactic acid to acetic acid is a good indicator of the efficiency of the silage fermentation [71, 72]. The ratios were according to the recommended values reported by Kaldmae et al. [73]., Filya et al. [74]. of 3:1; therefore, the silage quality was found to be excellent. Insignificantly, low concentration of propionic acid, not exceeding 1\%, was detected in the six silages while butyric acid was undetectable (not shown in the table). Butyric and propionic acids are uncommon end products of silage fermentation $[75,76]$. High butyric acid above $0.5 \%$ indicates clostridial fermentation of wet silages, associated with decreased DM intake in dairy cattle and can be related to increased ketosis [77-79]. Mean concentration of WSC contents was $20.86 \pm$ $0.56 \%$ on DM basis (Table 1). As observed, the concentrations of WSC varied insignificantly among the trenches after 30 days of ensilage. LAB utilized fermentable carbohydrates such as fructans, and the hexose sugars, that is, glucose, galactose, mannose, xylose, and arabinose present in the plant material during ensilage [80-82]. Haigh and Parker [83] suggested that the critical WSC concentration for successful preservation is $30 \mathrm{~g} / \mathrm{kg}$ DM. Molasses addition increases the metabolizable energy content of the silage and improves silage preservation $[84,85]$.

\subsection{Microbial enumerations}

Means of microbial enumerations, that is, aerobic bacteria, fungi, and LAB counts, were $1.8 \times 10^{4} \pm$ $0.15,1.1 \times 10^{4} \pm 0.10,7.3 \times 10^{8} \pm 0.12$, respectively (Table 1 ). Inoculation of the silages with microbial inoculants was found to increase LAB counts in the silages up to $10^{8} \mathrm{cfu} / \mathrm{g}$ silage and, currently, it was found to increase the accumulated lactic acid in the silage after 30 days of ensiling. Considering the present data, population size of $\operatorname{LAB}\left(10^{8}\right)$ in the silage is an indication of excellent bioconversion of forage. The addition of LAB inoculants at ensiling tends to ensure rapid and vigorous fermentation with rapid accumulation of lactic acid, low $\mathrm{pH}$ values in the initial stages of ensiling [86-88]. The effects of inoculation on microbial counts, fermentation products, and aerobic stability were determined by many investigators, Schmidt and Kung [89], Kung et al. [90]., Nishino et al. [91]., Ranjit and Kung [92] who indicated good preservation of silage with high counts of LAB, low yeasts counts when inoculated with Lactobacillus inoculants. No mycotoxins were detected in the trench silages (not shown in the table). Aflatoxins or mycotoxins are complex, carcinogenic compounds produced by fungi, such as Aspergillus, Fusarium and Penecillium, that produce toxins such as vomitoxin, ochratoxin A, patulin, penicillic acid, fumonisin, zearalenone, verrucarin, kojic acid, and T-2 toxin. All these aflatoxins have been associated with acute, chronic, and subchronic diseases of livestock [93-96].

The overall evaluation of the prepared Conocarpus silage indicated fast and efficient fermentation, low $\mathrm{pH}$ value, acceptable moisture content, acceptable contents of protein, fiber and fats, high lactic acid concentration, higher lactic acid to acetic acid ratio, undetectable concentrations of propionic and butyric acids, and low viable bacterial and fungal counts, and high LAB counts.

\subsection{Observations of palatability and performance of heifers}

Observations and data were recorded for a period of 4 months. Heifers on all dietary treatments grew satisfactorily with insignificant health problems. The experimental design had some limitations 
Table 2: Mean values of $\mathrm{pH}$, chemical composition percentage on DM basis and microbial enumerations in colony-forming units/gram (cfu/g) of fresh Conocarpus silage.

\begin{tabular}{lc}
\hline Nutritional parameter & Mean \pm SD* \\
\hline $\mathrm{pH}$ value & $4.2 \pm 0.12$ \\
$\mathrm{DM}$ & $35.10 \pm 4.00$ \\
$\mathrm{CP}$ & $11.18 \pm 0.07$ \\
Crude fats & $2.47 \pm 0.21$ \\
Crude fiber & $20.85 \pm 0.95$ \\
Organic matter & $19.53 \pm 0.53$ \\
Lactic acid & $4.95 \pm 0.32$ \\
Acetic acid & $1.47 \pm 0.01$ \\
Ratio of lactic acid: acetic acid & $3.38 \pm 0.11: 1.0$ \\
Total soluble carbohydrates (WSC) & $20.86 \pm 0.56$ \\
Aerobic bacteria & $1.8 \times 10^{4} \pm 0.15$ \\
Fungi (yeasts and molds) & $1.1 \times 10^{4} \pm 0.10$ \\
LAB & $7.3 \times 10^{8} \pm 0.12$ \\
\hline
\end{tabular}

*Standard deviation.

because each pen of animals was considered as an individual treatment group. Hence, the statistical evaluation of feed consumption was limited due to insufficient replication of pens with uniformly weighed heifers. Nevertheless, comparative animal performance parameters were clearly observed during the trial. After the adjustment period of 28 days, the heifers were accustomed to the formulated silage-containing rations. All grouped heifers of T2 to T6 positively responded to silage palatability compared to the heifers group of control dietary treatment T1. Means of DM intake and live weight gains of heifers during the entire 120 day-trial are shown in Table 3. The DM intake of $\mathrm{T} 2$ and T3 were $11.23 \pm 1.43$ and $11.4 \pm 2.14 \mathrm{~kg}$, respectively. Difference in DM intake of T2 and T3 heifers was not significant when compared to that of control treatment T1 heifers $(10.00 \pm$ $0.58 \mathrm{~kg}$ ) as shown in Table 3. Remarkably, DM intake significantly appeared high compared to the control treatment $\mathrm{T} 1(p \leq 0.05) 13.09 \pm 2.79,13.61 \pm 2.54$, and $13.20 \pm 2.17 \mathrm{~kg}$ in dietary treatments $\mathrm{T} 4$, T5, and T6, that contained 40, 50, and 60\% silage, respectively. The grouped heifers of T2 to T6 having silage in their feed rations had slower growth rates in the beginning period, compared to the control group, but then, improved their growth rates quite fast. Daily feed DM intake increased linearly with the advancing age and weights of animal groups during the 4 months study. Higher feed DM intake and increased live weight gains were observed in the animal groups receiving the highest proportions of silage in their diets. Means of average daily DM intake in dietary treatments T1, T2, T3, T4, T5, and T6 were $10.00 \pm 0.58,11.23 \pm 1.43,11.4 \pm 2.14,13.09 \pm 2.79,13.61 \pm 2.54$, and $13.20 \pm 2.17 \mathrm{~kg}$, respectively (Table 3 ). An overall mean growth rate of the heifers of T2 group was the highest followed by T3, T4, T5, and T6 groups. However, the overall differences in the live weight gains of heifers were not significant $(p>0.05)$ among the six dietary treatments even after the adjustment period. It was quite apparent that high level DM intake by the heifers receiving a high proportion of DM silages was associated with proportionately high daily live weight gain and FCR as shown in Table 3. However, it appeared that the conventional roughage could be substituted at the levels of 30-40\% Conocarpus DM silage. The results seemed to be similar to those reported by Ly [97] where he studied the effect of inclusion of DM-ensiled cassava leaves in experimental diets for growing 
Table 3: Daily DM intake (kg), live weight gain $(\mathrm{kg})$ and FCR $\mathrm{kg} \mathrm{DM} / \mathrm{kg}$ gain of dairy heifers.

\begin{tabular}{lccr}
\hline Dietary treatments* & DM intake $\pm \mathrm{SD}^{* *}$ & Weight gain $\pm \mathrm{SD}$ & FCR \\
\hline T1 & $10.00 \pm 0.58$ & $1.07 \pm 0.26$ & 10.0 \\
T2 & $11.23 \pm 1.43$ & $1.20 \pm 0.35$ & 9.9 \\
T3 & $11.4 \pm 2.14$ & $1.12 \pm 0.31$ & 10.6 \\
T4 & $13.09 \pm 2.79$ & $1.11 \pm 0.34$ & 12.4 \\
T5 & $13.61 \pm 2.54$ & $1.15 \pm 0.45$ & 12.6 \\
T6 & $13.20 \pm 2.17$ & $0.99 \pm 0.38$ & 15.0 \\
\hline
\end{tabular}

*Refer to Table 1 footnote for description of dietary treatments. **Standard deviation.

pigs that currently improved daily live weight gains and the FCR, without affecting the animals' health or overall performance. Research studies carried out by Huhtanen et al. [98, 99]. and experimental investigations conducted by Dhiman and Satter [100] at the US Dairy Forage Research Center, assessed the performance of dairy cows fed with formulated diets with different proportions of alfalfa silage and corn silage mixed with concentrates of high-moisture corn, soybean meal, roasted soybeans, and tallow. They observed a good animal performance for all diets, with a slight advantage for the corn silage diets. Kaiser [101] conducted field trials and reported that high quality silage can be successfully used in finishing diets for cattle to support satisfactory animal performance, producing high quality carcass and meat suitable for the domestic market, and significantly improving net returns per head. Sauer et al. [102]. observed that dairy heifers fed on a forage mixture of corn silage and formic acid-treated alfalfa silage ration had greater heart girths and wither heights. Furthermore, Cherney et al. [103]. observed no palatability problems though their research studies reported that grass silage can produce as much milk per cow as alfalfa silage when rations are balanced. Rodrigues et al. [104], Barrière et al. [105]., Pereira et al. [106] and Chizzotti et al. [107]. all reported satisfactory DM intake with appropriate concentrate levels of diets containing grass hay or silage as roughage.

Levels of NDF (\%),ADF (\%), digestible dry matter (DDM) (\%), digestible energy (DE) (MJ) and metabolizable (ME) (MJ) of the six formulated rations are illustrated Table 4. Significant differences $(p \leq 0.05)$ were observed among the treatments in DM digestibility, which obviously was associated with a lower crude fiber contents in the diets. The relationships between dietary NDF and voluntary DM intakes, DDM and net energy (DE, ME) by dairy heifers were evaluated. Dietary NDF, DM intakes, DE and ME ranged from 19.7 to $42.4 \%, 10.0$ to $13.6 \mathrm{~kg} /$ days, 2.3 to $2.7 \mathrm{MJ} / \mathrm{kg}$, and 2.0 to $2.3 \mathrm{MJ} / \mathrm{kg}$, respectively among the six dietary groups (Table 4). These variations were referred as a result of variations in proportions of silage and conventional forage (alfalfa hay and straw) in the formulated diets. In this trial, the results had clearly shown that significantly higher DDM of dietary treatments T4 and T5 was associated with lower concentration of crude fibers (Table 4) and in turn had significantly increased DM intake $(p \leq 0.05)$. In this feeding trial, DDM feed actually digested by animals was estimated in range of 65.6 to $81.1 \%$ among the six dietary groups (Table 4), which was quite high. High quality feeds have a DDM of over 65\%, while feeds below 55\% DDM are of poor quality and will not maintain live weight [108]. Crude fibers comprise of ADF, such as cellulose and lignin, and NDF such as hemicelluloses. ADF fractions appear to be the determinant factors for feed digestibility and DM intake of ruminants. Our findings are consistent with those of previous palatability and feeding studies of complete rations including crude fibers (NDF, ADF) fed to dairy cattle, sheep, and goats [109, 110]. Total fiber (NDF, ADF) concentrations of diets are effective basis 
Table 4: Relationship variations of NDF and ADF (\%), DM digestibility (DDM) (\%), digestible energy (DE), metabolizable energy (ME) (MJ/kg DM), DM intake and live weight gain (kg/days) for dairy heifers.

\begin{tabular}{lccccccc}
\hline $\begin{array}{l}\text { Dietary } \\
\text { treatments* }\end{array}$ & NDF & ADF & DDM & DE & ME & DM intake & $\begin{array}{c}\text { Live weight } \\
\text { gain }\end{array}$ \\
\hline T1 & 42.4 & 30.0 & 65.6 & 2.7 & 2.3 & 10.00 & 1.07 \\
T2 & 30.1 & 24.3 & 70.0 & 2.5 & 2.2 & 11.23 & 1.20 \\
T3 & 42.2 & 27.4 & 67.6 & 2.5 & 2.1 & 11.4 & 1.12 \\
T4 & 27.2 & 15.8 & 76.6 & 2.3 & 2.0 & 13.09 & 1.11 \\
T5 & 19.7 & 10.0 & 81.1 & 2.4 & 2.1 & 13.61 & 1.15 \\
T6 & 42.1 & 21.0 & 72.5 & 2.4 & 2.0 & 13.20 & 0.99 \\
\hline
\end{tabular}

*Refer to Table 1 footnote for description of dietary treatments. Values in the same column are significantly different $(p \leq 0.05)$.

of exchanging fiber sources in feedlot diets, and small increases in dietary NDF in feedlot diets might increase net energy without major changes in feed efficiency [111].

Potentially, the findings of this experimental feeding trial showed that grossly $40 \%$ of the conventional roughage could be replaced by palatable silage made from Conocarpus greenery browse residues. There are possibilities of a higher levels of silage addition to the feeding diets of dairy heifers upon further long-term studies.

\subsection{Cost/benefit}

The cost/benefit confirmed a feasible, low cost and competitive product where the cost was calculated to be Kuwaiti Dinar (KD) 33/t silage, and the breakeven point will be achieved after 30 months when 3,159 $\mathrm{t}$ shall have been produced. Additional analysis was carried out to estimate the price for silage that would generate an acceptable profit in a shorter period of time where this price has been determined to be KD 38.31. Based on this selling price, the prices of mixed and complete feed ingredients: concentrate mixture, alfalfa hay/straw, and silage, were calculated to sell the product as a complete feed and not only silage. Regardless of the mixture, the price would still be competitive compared to imported commercial feeds. It is suggested that effective low-cost feed roughages ingredients will be provided to the hands of farmers and animal breeders in Kuwait. The profitability and sustainability of dairy productivity and farming depends vitally on efficient environmentally friendly management practices with a minimum monetary cost [112]. Feed management is an important control point for total farm profitability and sustainability where feed costs represent up to $60 \%$, of total expenses [113-115]. The total costs of raising dairy heifers are contributing to the operating expenses of a dairy farm [116-121].

\section{CONCLUSIONS}

Due to the chronic shortage of local animal feeds, efforts were urged to explore the possibility of C. lancifolius browse residues that might be utilized and ensiled as an upgraded and cost-effective feed ingredient alternative to forages in livestock feeding systems. An excellent potential was indicated for using greenery browse residues of landscape Conocarpus as a partial substitute of the expensive imported alfalfa and straw. Silage making of Conocarpus greenery browse residues was promoted 
as a pioneering approach to alleviate animal feed shortage, as well as to utilize renewable locally available raw resources in Kuwait. Palatability and animal performance trials were performed on dairy heifers where high feed DM intake and live weight gains were observed within the animal groups receiving high proportions of 40,50, and $60 \%$ of silage in their diets. Overall findings showed that grossly $40 \%$ of the conventional roughage could be replaced by the ensiled Conocarpus greenery browse residues. The preliminary feasible analysis of the pilot-scale production of Conocarpus silage proposing a low cost per unit of KD 33/t of product, since the break-even point would be achieved after 30 months. The financial analysis confirmed that the project will be feasible and the product will be competitive. The flow of consolidating cooperation through cross-country contributed networks could be achieved among the scientists and the livestock producers.

\section{ACKNOWLEDGMENTS}

The authors highly appreciate the continuous technical supervision and financial support of Kuwait Institute for Scientific Research (KISR). The Islamic Development Bank (IDB) is highly acknowledged for the financial grant offered to this study. The working team is sincerely grateful to the House of Development for Agricultural Contracting Company (HOD) and Al-Ahmad Company for the in-kind facilities and continuous supervision of the experimental working sites and dairy farms at Al-Sulaibiya and Kabd areas.

\section{REFERENCES}

[1] Osman, A.E., Makawi, M. \& Ahmed, A., Potential of the indigenous desert grasses of the Arabian Peninsula for forage production in a water-scarce region. Grass and Forage Science, 63, pp. 495-503, 2008. doi: http://dx.doi.org/10.1111/j.1365-2494.2008.00656.x

[2] Al-Senafy, M. \& Abraham, J., Vulnerability of groundwater resources from agricultural activities in southern Kuwait. Agricultural Water Management, 64, pp. 1-15, 2004. doi: http://dx. doi.org/10.1016/S0378-3774(03)00195-1

[3] Peacock, J.M., Ferguson, M.E., Alhadrami, G.A., Mccann, I.R., Al Hajoja, A., Saleh, A. \& Karnik, R., Conservation through utilization: a case study of the indigenous forage grasses of the Arabian Peninsula. Journal of Arid Environments, 54, pp. 15-28, 2003. doi: http://dx.doi. org/10.1006/jare.2001.0895

[4] Ghazanfar, S.A. \& Fisher, M., Vegetation of the Arabian Peninsula, Kluwer Academic Publishers: London, UK, 1998. doi: http://dx.doi.org/10.1007/978-94-017-3637-4

[5] Taha, F.K., Razzaque, M.A., Suleiman, A.R \& Nassef, A.A., Rangelands: A resource under siege. Proceedings of the Second International Rangeland Congress, eds. P.J. Joss, P.W. Lynch, O.B. Williams, 1986.

[6] Razzaque, M.A. \& AL-Nasser, A., Status of animal production sub-sector and animal origin foods in Kuwait and recommended measures for improvement. Technical Report. Kuwait Institute for Scientific Research, Report No. KISR 6722, 2003.

[7] Business Analytic Center (BAC), Animal Feed Market in Kuwait: Business Report 2011, Kuwait, 2011.

[8] Ministry of Planning, Agriculture and livestock. In: Annual Statistical Abstract, Chapter VII. 39, pp. 127-138 Kuwait, 2002.

[9] Ministry of Planning, Agriculture and livestock. In: Annual Statistical Abstract. Chapter VII. 40, pp. 143-154 Kuwait, 2004.

[10] Gabler, M.T., Tozer, P.R. \& Heinrichs, A.J., Development of a cost analysis spreadsheet for calculating the costs to raise a replacement dairy heifer. Journal of Dairy Science, 83, pp. 1104-1109, 2000. doi: http://dx.doi.org/10.3168/jds.S0022-0302(00)74975-7 
[11] Zaroug, M., Importance of fodder trees and shrubs for the productivity of rangelands and agriculture systems in the near east. FOA Corporate Document Repository, Food and Agriculture Organization, (FAO): Italy, 1985.

[12] Bhat, N.R., Suleiman, M.K., Al-Menaie, H., Al-Ali, E.H., AL-Mulla, L., Christopher, A., Lekha, V.S., Ali, S.I \& George, P., Polyacrylamide polymer and salinity effects on water requirement of conocarpus lancifolius and selected properties of sandy loam soil, European Journal of Scientific Research, 25(4), pp. 549-558, 2009.

[13] Baroon, Z., Razzaque, M.A. \& Al-Anjari, H., Evaluation of greenery residues for animal feeding: Chemical and microbiological studies on plants and silages. Kuwait Institute for Scientific Research. Technical Report No. KISR 6163, Kuwait, 2001.

[14] Razzaque, M.A., Scharp, D., Al-Mutawa, T., Al-Muhanna, M., Abbas, S., Shalabi, A., ElSawy, E., Al- Awadhi, A., Mulla, F., \& El-Sanousi, A., Field and laboratory investigation of calf mortality in Kuwait and its economic impact on dairy production. Kuwait Institute for Scientific Research, Report No. KISR6004, Kuwait, 2001.

[15] Suleiman, M.K., Bhat, N.R., Abdal, M.S. \& Bellen, R.R., Testing newly introduced ornamental plants to the arid climate of Kuwait. Archives of Agronomy and Soil Science, 51, pp. 469-479, 2005. doi: http://dx.doi.org/10.1080/03650340500094807

[16] ICBA, Strategic Plan 2008-2012. International Center for Biosaline Agriculture, UAE, 2009.

[17] Al-Surrayai, T. \& Baroon, Z., Investigation of the chemical and microbiological quality of fresh plants, silages and calves meat. Technical report KISR 7764, Kuwait Institute for Scientific Research, Kuwait, 2005.

[18] Wensvoort, J., Browse silage in the UAE. Wildlife Middle East News, 3(1). ISSN 1990-8237. UAE, 2008.

[19] Baroon, Z., Razzaque, M.A., Bedair, M. \& Abbas, S., Greenery residues as livestock feed. Phase II: Pilot-scale production of silage and animal response studies. Progress report KISR 7892, Kuwait Institute for Scientific Research, Kuwait, 2003.

[20] Baroon, Z., Razzaque, M.A. \& Mufleh, A., Ensilage of greenery residues as animal feed. Phase I: Pilot-scale production and palatability studies. Final report KISR 7194, Kuwait Institute for Scientific Research, Kuwait, 2004.

[21] Baroon, Z., Abbas, S., Razzaque, M.A. \& Bedair, M., Greenery residues as livestock feed. Phase II: Pilot-scale production of silage and animal response studies. Progress report KISR 8177, Kuwait Institute for Scientific Research, Kuwait, 2006.

[22] Marley, C.L., Fychan, R., Fraser, M.D., Sanderson, R. \& Jones, R., Effects of feeding different ensiled forages on the productivity and nutrient-use efficiency of finishing lambs. Grass and Forage Science, 62, pp. 1-12, 2007. doi: http://dx.doi.org/10.1111/j.1365-2494.2007.00556.x

[23] Knickey, M., Possibilities to Improve Silage Conservation, Effects of Crop, Ensiling Technology and Additives, Doctoral thesis, Swedish University of Agricultural Sciences: Uppsala. ISSN 1652-6880, 2005.

[24] Asbell, G., Kipnis, T., Titterton, M., Hen, Y., Azrieli A. \& Weinberg, Z.G., Examination of a technology for silage making in plastic bags. Animal Feed Science and Technology, 91, pp. 213-222, 2001. doi: http://dx.doi.org/10.1016/S0377-8401(01)00239-5

[25] El Shaer, H.M., Halophytes and salt-tolerant plants as potential forage for ruminants in the near East region. Small Ruminant Research, 91, pp. 3-12, 2010. doi: http://dx.doi.org/10.1016/ j.smallrumres.2010.01.010

[26] Woolford, M., \& Pahlow, G., The silage fermentation. In: Microbiology of Fermented Foods, ed. B.J.B Wood, Blackie Academic and Professional: London pp. 73-102, 1998. doi: http://dx. doi.org/10.1007/978-1-4613-0309-1 3 
[27] Kung, L. \& Muck, R.E., Animal response to silage additives, Proceedings of Silage: Field Feedbunk, North American Conference, the Silage: Field to Feedbunk North American Conference, Pennsylvania, USA, pp. 200-210, 1997.

[28] McDonald, P., Henderson, A.R. \& Heron, S.J.E., The Biochemistry of Silage $2^{\text {nd }}$ edition. Chalcombe Publications, Marlow: United Kingdom, 340, 1991.

[29] Woodlford, M.K., The chemistry of silage. In: The Silage Fermentation, ed. M.K. Woodford, Marcel Dekker: New York, pp. 71-132, 1984.

[30] Whittenbury, R., Microbiology of grass silage. Process Biochemistry, pp. 27-31, 1968.

[31] Nkosi, B.D., Meeske, R., Palic, D. \& Langa T., Laboratory evaluation of an inoculant for ensiling whole crop maize in South Africa. Animal Feed Science and Technology, 150, pp. 144-150, 2009. doi: http://dx.doi.org/10.1016/j.anifeedsci.2008.07.008

[32] Sucu, E. \& Filya, I., Effects of homofermentative lactic acid bacterial inoculants on the fermentation and aerobic stability characteristics of low dry matter corn silages. Turkish Journal of Veterinary and Animal Sciences, 30, pp. 83-88, 2006.

[33] Driehuis, F., Oude Elferink, S.W.J.H. \& van Wikselaar, P.G., Fermentation characteristics and aerobic stability of grass silage inoculated with Lactobacillus buchneri, with or without homofermentative lactic acid bacteria. Grass and Forage Science, 56, pp. 330-343, 2001. doi: http:// dx.doi.org/10.1046/j.1365-2494.2001.00282.x

[34] Meeske, R. \& Basson, H.M., The effect of a lactic acid bacterial inoculant on maize silage. Animal Feed Science and Technology, 70, pp. 239-247, 1998. doi: http://dx.doi.org/10.1016/ $\underline{\text { S0377-8401(97)00066-7 }}$

[35] Muck, R.E., Silage inoculation: inoculation of silage and its effects on silage quality. US Dairy Forage Centre, Informational Conference with Dairy and Forage Industries US Dairy Forage Research Center, Madison, WI, USA, pp. 43-51, 1996.

[36] Wittenberg, K.M., Ingalls, J.R. \& Devlin. T.J., The effect of lactobacteria inoculation on corn silage preservation and feeding value for growing beef animals and lamb. Canadian Journal of Animal Science, 63, pp. 917-924, 1983. doi: http://dx.doi.org/10.4141/cjas83-106

[37] Aridland Agriculture Department (AAD), Master plan for development of Kuwait's agricultural sector (1995-2015), Appendix III. Current and projected animal and crop production, Kuwait Institute for Scientific Research, Report No. KISR 4615, Kuwait, 1995.

[38] Ilian, M.A., Razzaque, M.A. \& Salman, A.J., Unconventional feeds for sheep: Effects on performance and meat quality and composition. Biological Wastes, 24(2), pp. 115-125, 1988. doi: http://dx.doi.org/10.1016/0269-7483(88)90054-7

[39] Razzaque, M.A., Mohammed, S.A., Al-Mutawa, T. \& Bedair, M., Growth, reproduction and milk yield of Holstein Friesian heifers born and adapted in Kuwait, Pakistan Journal of Nutrition, 8(8), pp. 1159-1163, 2009.

[40] Bahman, A.M., Rook, J.A. \& Topps, J.H., The performance of dairy cows offered drinking water of low or high salinity in a hot arid climate. Animal Production, 57(1), pp. 23-28, 1993. doi: http://dx.doi.org/10.1017/S0003356100006565

[41] Armstrong, D.V., Malik, R., Kraynick, R., Razzque, M.A. \& Abdulla, T., Assessment of Kuwait's dairy sector The dairy cattle industry: A review of the production constraints and proposals for resolving some of them, In: Master Plan for Development of Kuwait's Agricultural Sector (1995-2015). Kuwait Institute for Scientific Research, Report No. KISR4615, Kuwait, 1995.

[42] AOAC, Official Methods of Analysis $15^{\text {th }}$ Edition. Association of Official Analytical Chemists: Arlington, Virginia, USA, 2002.

[43] Dewar, W.A. \& McDonald, P., Determination of dry matter in silage by distillation with toluene, Journal of the Science of Food and Agriculture, 12(11), pp. 790-795, 1961. doi: http://dx. doi.org/10.1002/jsfa.2740121112 
[44] Goering, H.K. \& Van Soest, P.J., Forage fiber analysis, In: Agricultural Handbook No. 379, Agricultural Research Service, U.S. Department of Agriculture, pp. 197-218, 1970.

[45] McDonald, P. \& Henderson, A.R., Determination of water-soluble carbohydrates in grass. Journal of the Science of Food and Agriculture, 15(6), pp. 395-398, 1964. doi: http://dx.doi. org/10.1002/jsfa.2740150609

[46] Ohmomo, S., Tanaka, O. \& Kitamoto, H., Analysis of organic acids in silage by highperformance liquid chromatography. Bulletin of the National Grassland Research Institute, 48, pp. 51-56, 1993.

[47] National Research Council (NRC), Nutrient requirements of dairy cattle, 7th edn., National Academic of Sciences: Washington DC, USA, 2001.

[48] Zanton, G.I. \& Heinrichs. A.J., Analysis of nitrogen utilization and excretion in growing dairy cattle. Journal of Dairy Science, 91, pp. 1519-1533, 2008. doi: http://dx.doi.org/10.3168/jds. 2007-0624

[49] Duncan, D.B., Multiple range and multiple F test. Biometrics, 11, pp. 1-42, 1955. doi: http:// dx.doi.org/10.2307/3001478

[50] Payne, R.L., Lavergne, T.K. \& Southern, L.L., A comparison of two sources of phytase in liquid and dry forms in broilers. Poultry Science, 84, pp. 265-272, 2005.

[51] Ruppel, K.A., Pitt, R.E., Chase, L.E. \& Galton, D.M., Bunker silo management and its relationship to forage preservation on dairy farms. Journal of Dairy Science, 78, pp. 141-153, 1995. doi: http://dx.doi.org/10.3168/jds.S0022-0302(95)76624-3

[52] Muck, R.E., Savoie, P. \& Holmes, B.J., Factors influencing density in bunker silos. U.S. Dairy Forage Research Center 2002 Research Report, pp. 11-13, 2003.

[53] Woolford, M. \& Pahlow, G., The silage fermentation. In: Microbiology of Fermented Foods, ed B.J.B. Wood, Blackie Academic and Professional: London, pp. 73-102, 1998. doi: http:// dx.doi.org/10.1007/978-1-4613-0309-1 3

[54] McDonald, P., Henderson, A.R. \& Heron, J.E., The Biochemistry of Silage, 2nd Edition, Marlow, United Kingdom: Chalcombe Publications, 340, 1991.

[55] Toruk, F. \& Koc, F., Effect on silage quality and aerobic stability of different compaction levels in sunflower silage. Bulgarian Journal of Agricultural Science, 15(3), pp. 269-275, 2009.

[56] Muck, R.E., Factors influencing silage quality and their implications for management. Journal of Dairy Science, 7, pp. 2992-3002, 1998.

[57] Peterson, K., Ensiling of forages: Factors affecting silage fermentation and quality. Swedish University of Agricultural Sciences, Department of Animal Nutrition and Management: Uppala, p. 46, 1988.

[58] Jaster, E.H. \& Moore, K.J., Quality and fermentation of enzyme-treated alfalfa silages at three moisture concentrations. Animal Feed Science and Technology, 31, pp. 261-268, 1990. doi: http://dx.doi.org/10.1016/0377-8401(90)90130-Z

[59] Garcia, A.D., Olson, W.G., Otterby, D.E., Linn, J.G. \& Hansen, W.P., Effects of temperature, moisture, and aeration on fermentation of alfalfa silage. Journal of Dairy Science, $\mathbf{7 2}$, pp. 93-103, 1989. doi: http://dx.doi.org/10.3168/jds.S0022-0302(89)79084-6

[60] Fouda, S.M.I., Nutritional evaluation of silage of some agricultural by-products. Thesis, Faculty of Agriculture, Al-Azhar University, 2005.

[61] Shehata, S.M., El Shimi, S.A., Elkattan, M.H., Ali, B.E., El-Housseini, M., Integrated waste management for rural development in Egypt. Journal of Environmental Science and Health, 39, pp. 341-349, 2004. doi: http://dx.doi.org/10.1081/ESE-120027526

[62] Huhtanen, P., Rinne, M. \& Nousiainen, J., Evaluation of the factors affecting silage intake of dairy cows: a revision of the relative silage dry-matter intake index. Animal, 1, pp.758-770, 2007. doi: http://dx.doi.org/10.1017/S175173110773673X 
[63] Kung, L., Jr., \& Shaver, R.D., Interpretation and use of silage fermentation analysis reports. Focus on Forage, 3, pp. 1-5, 2001.

[64] Jalc1, D., Laukova, A., Simonova, M., Varadyova, Z. \& Homolka, P., The use of bacterial inoculants for grass silage: their effects on nutrient composition and fermentation parameters in grass silages. Czech Journal of Animal Science, 54, pp. 84-91, 2009.

[65] Selmer-Olsen, I., Henderson, A.R., Robertson, A.R. \& McGinn, A., Cell wall degrading enzymes for grass silage. 1. The fermentation of enzyme treated silage in laboratory silos. Grass and Forage Science, 48, pp. 45-54, 1993. doi: http://dx.doi.org/10.1111/j.1365-2494.1993.tb01835.x

[66] Mertens, D.R., Impact of NDF content and digestibility on dairy cow performance. Proceedings of $27^{\text {th }}$ Annual Western Canadian Dairy Seminar. Red Deer: Alberta, Canada, 2009.

[67] Mertens, D.R., Regulation of forage intake. In: Forage Quality, Evaluation, and Utilization, ed. G.C. Fahey Jr. American Society of Agronomy: Madison, Wisconsin, USA, pp. 450-493, 1994.

[68] Zimmerman, C., Silage Fermentation Analysis, Blue Seal Feeds Inc., 2002.

[69] Kung, L., Jr., Robinson, J.R., Ranjit, N.K., Chen, J.H. \& Golt, C.M., Microbial populations, fermentation end products, and aerobic stability of corn silage treated with ammonia or a propionic acid-based preservative. Journal of Dairy Science, 83, pp. 1479-1486, 2000. doi: http:// dx.doi.org/10.3168/jds.S0022-0302(00)75020-X

[70] Filya, I. \& Sucu, E., The effects of lactic acid bacteria on the fermentation, aerobic stability and nutritive value of maize silage. Grass and Forage Science, 65(4), pp. 446-455, 2010. doi: http://dx.doi.org/10.1111/j.1365-2494.2010.00763.x

[71] Piltz, J.W. \& Kaiser, A.G., Principles of silage preservation. In: Top Fodder Successful Silage, eds. A.G Kaiser., J.W Piltz., H.M Burns. \& N.W Griffiths, Dairy Australia and New South Wales Department of Primary Industries: Orange, NSW, Australia, pp 25-56, 2004.

[72] Kung, L., Jr. \& M. R. Stokes, M.R., Analyzing silages for fermentation end products. Available at http://ag.udel.edu/departments/anfs/faculty/kung/articles/analyzing_silages_for_fermentati. htm., 2001.

[73] Kaldmae, H., Kart, O., Olt, A., Selge, A. \& Keres, I., Inoculant effects on red clover silage: fermentation products and nutritive value. Agronomy Research, 7(2), pp. 793-800, 2009.

[74] Filya, I., Muck, R.E. \& Contreras-Govea, F.E., Inoculant effects on alfalfa silage: fermentation products and nutritive value. Journal of Dairy Science, 90, pp. 5108-5114, 2007. doi: http:// dx.doi.org/10.3168/jds.2006-877

[75] Ward, R.T., Fermentation analysis: use and interpretation. Proceedings of Tri-State Dairy Nutrition Conference, Fort: Indiana, USA, pp. 117-136, 2000.

[76] Rees, T.J., Review of the Literature-the Development of a Novel Antifungal Silage Inoculant, Doctoral Research Thesis, 1997.

[77] Huhtanen, P., Rinne, M. \& Nousiainen, J., Evaluation of the factors affecting silage intake of dairy cows: a revision of the relative silage dry-matter intake index. Animal, 1, pp. 758-770, 2007. doi: http://dx.doi.org/10.1017/S175173110773673X

[78] Oetzel, G.R., Herd-Level Ketosis-Diagnosis and Risk Factors, Preconference Seminar 7C: Dairy Herd Problem Investigation Strategies: Transition Cow Troubleshooting, American Association of Bovine Practitions 40 ${ }^{\text {th }}$ Annual Conference, Vancouver, BC, Canada, 2007.

[79] Tveit, B., Lingaas, F., Svendsen, M. \& Sjaastad, Ø.V., Etiology of acetonemia in norwegian cattle. 1. effect of ketogenic silage, season, energy level, and genetic factors. Journal of Dairy Science, 75, pp. 2421-2432, 1992. doi: http://dx.doi.org/10.3168/jds.S0022-0302(92)78003-5

[80] Lima, R., Lourenço, M., Díaz, R.F., Castro, A. \& Fievez, V., Effect of combined ensiling of sorghum and soybean with or without molasses and lactobacilli on silage quality and in vitro rumen fermentation. Animal Feed Science and Technology, 155, pp. 122-131, 2010. doi: http:// dx.doi.org/10.1016/j.anifeedsci.2009.10.008 
[81] Iqbal, S., Bhati, S.A., Mahr-un-Nisa \& Sarwar, M., Influence of varying levels of organic green culture and enzose on silage characteristics of mott grass and its digestion kinetics in Nili-Ravi buffalo bulls. International Journal of Agriculture and Biology, 6, pp. 1011-1014, 2005.

[82] Ben-Ghedalia, D., Kabala, A., Miron, J. \& Yosef, E., Silage fermentation and in vitro degradation of monosaccharide constituents of wheat harvested at two stages of maturity. Journal of Agricultural and Food Chemistry, 43, pp. 2428-2431, 1995. doi: http://dx.doi.org/10.1021/ if00057a021

[83] Haigh, P.M. \& Parker, J.W.G., Effect of silage additives and wilting on silage fermentation, digestibility and intake, and on live weight change of young cattle. Grass and Forage Science, 40, pp. 429-436, 1985. doi: http://dx.doi.org/10.1111/j.1365-2494.1985.tb01774.x

[84] Nkosi, B.D., Meeske, R., Palic, D. \& Langa T., Laboratory evaluation of an inoculant for ensiling whole crop maize in South Africa. Animal Feed Science and Technology, 150, pp. 144-150, 2009. doi: http://dx.doi.org/10.1016/j.anifeedsci.2008.07.008

[85] Piltz, J.W. \& Kaiser, A.G., The use of molasses to improve the fermentation of low dry matter kikuyu grass silages. In: "Silage Making in the Tropics with Particular Emphasis on Smallholders", ed L Mannetje, FAO Plant Production and Protection Paper 161, pp. 165-166, 2000.

[86] Weinberg, Z.G., Khanal, P., Yildiz, C., Chen, Y. \& Arieli. A., Effects of stage of maturity at harvest, wilting and LAB inoculant on aerobic stability of wheat silages. Animal Feed Science and Technology, 158, pp. 29-35, 2010. doi: http://dx.doi.org/10.1016/j.anifeedsci.2010.03.006

[87] Kung, L., Jr. \& Ranjit, N.K., The effect of Lactobacillus buchneri and other additives on the fermentation and aerobic stability of barley silage. Journal of Dairy Science, 84, pp. 1149-1155, 2001. doi: http://dx.doi.org/10.3168/jds.S0022-0302(01)74575-4

[88] Pancholy, R. \& Mall, P.C., Requirement of bacterial inoculant and urea addition for ensiling of desert grass. Lasiurus scindicus. Journal of Arid Environments, 27, pp. 387-391, 1994. doi: http://dx.doi.org/10.1006/jare.1994.1073

[89] Schmidt, R.J. \& Kung, L., The effects of Lactobacillus buchneri with or without a homolactic bacterium on the fermentation and aerobic stability of corn silages made at different locations. Journal of Dairy Science, 93, pp. 1616-1624, 2010. doi: http://dx.doi.org/10.3168/jds.2009$\underline{2555}$

[90] Kung, L., Schmidt, R.J., Ebling, T.E. \& Hu, W., The effect of Lactobacillus buchneri 40788 on the fermentation and aerobic stability of ground and whole high-moisture corn. Journal of Dairy Science, 90(5), pp. 2309-2314, 2007. doi: http://dx.doi.org/10.3168/jds.2006-713

[91] Nishino, N., Wada, H., Yoshida, M. \& Shiota. H., Microbial counts, fermentation products, and aerobic stability of whole crop corn and a total mixed ration ensiled with and without inoculation of Lactobacillus casei or Lactobacillus buchneri. Journal of Dairy Science, 9, pp. 2563-2570, 2004. doi: http://dx.doi.org/10.3168/jds.S0022-0302(04)73381-0

[92] Ranjit, N.K. \& Kung, L., The effect of Lactobacillus buchneri, Lactobacillus plantarum, or a chemical preservative on the fermentation and aerobic stability of corn silage. Journal of Dairy Science, 83(3), pp. 526-268, 2000. doi: http://dx.doi.org/10.3168/jds.S0022-0302(00)74912-5

[93] Widstrom, N.W., The aflatoxin problem with corn grain. Advances in Agronomy, 56, pp. 219-280, 1996. doi: http://dx.doi.org/10.1016/S0065-2113(08)60183-2

[94] Ingalls, J.R., Influence of deoxynivalenol on feed consumption by dairy cows. Animal Feed Science and Technology, 60, pp. 297-300, 1996. doi: http://dx.doi.org/10.1016/0377-8401(96) $\underline{00984-4}$

[95] Charmley, E., Trenholm, H.L., Thompson, B.K., Vudathala, D., Nicholson J.W.G. \& Charmley, L.L., Influence of level of deoxynivalenol in the diet of dairy cows on feed intake, milk production and its composition. Journal of Dairy Science, 76, pp. 3580-3587, 1993. doi: http://dx.doi. org/10.3168/jds.S0022-0302(93)77697-3 
[96] Shurtleff, M.C., Compendium of corn diseases, 2nd edn, pp. 51-60, American Phytological Society: Minnesota, USA, APS Press, pp. 43-63, 1980.

[97] Ly, N.T.H., The use of ensiled cassava leaves for feeding pigs on-farm in central Vietnam. Workshop-seminar "Forages for Pigs and Rabbits" MEKARN-CelAgrid, Phnom Penh, Cambodia, 2006.

[98] Huhtanen, P., Rinne, M. \& Nousiainen, J., Evaluation of concentrate factors affecting silage intake of dairy cows: a development of the relative total diet intake index. Animal, 2, pp. 942-953, 2008. doi: http://dx.doi.org/10.1017/S1751731108001924

[99] Huhtanen, P., Rinne, M. \& Nousiainen, J., Evaluation of the factors affecting silage intake of dairy cows: a revision of the relative silage dry-matter intake index, Animal, 1, pp. 758-770, 2007. doi: http://dx.doi.org/10.1017/S175173110773673X

[100] Dhiman, T.R., \& Satter, L.D., Yield responses of dairy cows fed different proportions of alfalfa silage and corn silage. Journal of Dairy Science, 80, pp. 2069-2082, 1997. doi: http:// dx.doi.org/10.3168/jds.S0022-0302(97)76152-6

[101] Kaiser, A.G., Alternative Finishing Strategies for the Production of High Quality Beef, Medical Research Council (MRC) Report for DAN.040, 1993.

[102] Sauer, F.D., Kramer, J.K.G. \& Cantwell, W.J., Antiketogenic effects of monensin in early lactation. Journal of Dairy Science, 72, pp. 436-442, 1989. doi: http://dx.doi.org/10.3168/ jds.S0022-0302(89)79125-6

[103] Cherney, D.J.R., Cherney, J.H. \& Chase, L.E., Influence of lucerne/fescue silage mixtures on milk production of early-lactation Holstein cows. Journal of Animal Feed and Science, 11, pp. 555-564, 2002.

[104] Rodrigues, M.A.M., Fonseca, A.J.M., Sequeira, C.A. \& Dias-da-Silva, A.A., Digestion kinetic parameters from an in vitro gas production method as predictors of voluntary intake of forage by mature ewes. Animal Feed Science and Technology, 95, pp. 133-142, 2002. doi: http://dx.doi.org/10.1016/S0377-8401(01)00326-1

[105] Barrière, Y., Dias Gonçalves, G., Emile, J.C. \& Lefèvre, B., Higher Intake of DK265 Corn Silage by Dairy Cattle. Journal of Dairy Science, 87, pp. 1439-1445, 2004. doi: http://dx.doi. org/10.3168/jds.S0022-0302(04)73294-4

[106] Pereira, D.H., Pereira, O.G., Silva, B.C., Leão, M.I., Valadares Filho, S.C. \& Garcia, R., Nutrient intake and digestibility and ruminal parameters in beef cattle fed diets containing Brachiaria brizantha silage and concentrate at different ratios. Animal Feed Science and Technology, 140, pp. 52-66, 2008. doi: http://dx.doi.org/10.1016/j.anifeedsci.2007.02.012

[107] Chizzotti, F.H.M., Pereira, O.G., Valadares Filho, S.C., Chizzotti, M.L., Leão, M.I., Pereira, D.H. \& Tedeschi, L.O., Intake, digestibility, ruminal parameters, and microbial protein synthesis in crossbred steers fed diets based on Brachiaria grass silage and sorghum silage. Brazilian Journal of Veterinary and Animal Science (Arquivo Brasileiro de Medicina Veterinária e Zootecnia), 61, pp. 1328-1338, 2009.

[108] Rymer, C., The measurement of forage digestibility in vivo, In: Forage Evaluation in Ruminant Nutrition eds. D.I. Givens., E. Owen., R.F.E. Axford.. \& H.M.Omed, CABI Publishing, CAB International: Oxon, UK, pp. 113-134, 2000.

[109] Arelovich, H.M., Abney, C.S., Vizcarra, J.A. \& Galyean, M.L., Effects of dietary neutral detergent fiber on intakes of dry matter and net energy by dairy and beef cattle: Analysis of published data. The Professional Animal Scientist, 24, pp. 375-383, 2008.

[110] Galyean, M.L. \& P. J. Defoor., Effects of roughage source and level on intake by feedlot cattle. Journal of Animal Science, 81, pp. E8-E16, 2003. 
[111] DiLorenzo, N. \& Galyean, M.L., Applying technology with newer feed ingredients in feedlot diets: do the old paradigms apply?. Journal of Animal Science, 88, pp. 123-132, 2010.

[112] Giger-Reverdin, S., Aufrkre, J., Sauvant, D., Demarquilly, C. \& Vermorel, M., Prediction of the energy values of compound feeds for ruminants. Animal Feed Science and Technology, 48, pp. 73-98, 1994. doi: http://dx.doi.org/10.1016/0377-8401(94)90113-9

[113] Razzaque, M.A., Bedair, M., Abbas, S. \& Al-Mutawa, T., Economic impact of calf mortality on dairy farms in Kuwait. Pakistan Veterinary Journal, 29(3), 97-101, 2009.

[114] Nennich, T.D., Harrison, J.H., Van Wieringen, L.M., Meyer, D., Heinrichs, A.J., Weiss, W.P., St-Pierre, N.R., Kincaid, R.L., Davidson, D., \& Block. E., Prediction of manure and nutrient excretion of dairy cattle. Journal of Dairy Science, 88, pp. 3721-3733, 2005. doi: http://dx. doi.org/10.3168/jds.S0022-0302(05)73058-7

[115] Gabler, M.T., Tozer, P.R. \& Heinrichs, A.J., Development of a cost analysis spreadsheet for calculating the costs to raise a replacement dairy heifer. Journal of Dairy Science, 83, 1104 1109, 2000. doi: http://dx.doi.org/10.3168/jds.S0022-0302(00)74975-7

[116] Hoffman, P.C., Simson, C.R. \& Wattiaux, M., Limit feeding of gravid Holstein heifers: effect on growth, manure nutrient excretion, and subsequent early lactation performance. Journal of Dairy Science, 90, pp. 946-954, 2007. doi: http://dx.doi.org/10.3168/jds.S0022$\underline{0302(07) 71578-3}$

[117] Zanton, G.I. \& Heinrichs, A.J., The effects of controlled feeding of a high-forage or highconcentrate ration on heifer growth and first-lactation milk production. Journal of Dairy Science, 90, pp. 3388-3396, 2007. doi: http://dx.doi.org/10.3168/jds.2007-0041

[118] Ettema, J.F. \& Santos, J.E.P., Impact of age at calving on lactation, reproduction, health, and income in first-parity Holsteins on commercial farms. Journal of Dairy Science, 87, pp. 2730-2742, 2004. doi: http://dx.doi.org/10.3168/jds.S0022-0302(04)73400-1

[119] Tozer, P.R. \& Heinrichs, A.J., What affects the costs of raising replacement dairy heifers: A multiple-component analysis. Journal of Dairy Science, 84, pp. 1836, 2001. doi: http://dx. doi.org/10.3168/jds.S0022-0302(01)74623-1

[120] Hoffman, P.C., Brehm, N.M., Price, S.G. \& Prill-Adams, A., Effect of accelerated post pubertal growth and early calving on lactation performance of primiparous Holstein heifers. Journal of Dairy Science, 79, pp. 2024-2031, 1996. doi: http://dx.doi.org/10.3168/jds.S0022$\underline{0302(96) 76575-X}$

[121] Hoffman, P.C. \& Funk, D.A., Applied dynamics of dairy replacement growth and management. Journal of Dairy Science, 75(9), pp. 2504-2516, 1992. doi: http://dx.doi.org/10.3168/ jds.S0022-0302(92)78012-6 